\title{
External Auditors and Earnings Management: Palestinian Evidence
}

\author{
D.O.I - 10.51201/Jusst12607
}

http://doi.org/10.51201/Jusst12607

\author{
Mohammed W. A. Saleh', DerarEleyan², Nafieh A.Assaf ${ }^{3}$ \\ 1,30partment of Accounting Information System, Palestine Technical University- Khadoori \\ ${ }^{2}$ Department of Applied Computing, Palestine Technical University- Khadoori
}

\begin{abstract}
Managers in large companies may manipulate earnings reports to suit their desire at the detriment of shareholders and other stakeholders. This may obstruct the companies and their sustainability. The objective of this study is to examine a relationship between external audit characteristics and Earnings Management (EM) in Palestine. Secondary data is collected for a sample of 480 observations of companies listed in the PSE for the period of 2010-2019. Earnings management is measured by the level of discretionary accruals using the modified Jones model (1995). The results show that external auditors' type is negative and significantly related to discretionary accruals and may reduce EM. However, external auditors' independence is positive and significantly related to discretionary accruals and may increase EM. Studying the impact of external auditors' characteristics on EMhave not been well researched in the past literature, especially in the Palestinian context.
\end{abstract}

Keywords: Earnings management, external auditors, Jones model (1995), Palestine.

\section{Introduction}

EM and integrity of financial reporting and disclosure have been subjects of discussion and concern among regulators, financial analysts, and accounting practitioners, especially after the sequence of prominent accounting crises and frauds involving renowned firms like Xerox, WorldCom, and Enron (Stubben, 2010). This integrity of financial disclosure is hardly achievable as managers sometimes connive with auditors to manipulate earnings with the goal of increasing their personal wealth at the detriment of shareholders (Kothari, Mizik \& Roychowdhury, 2015). Furthermore, despite the publication of corporate governance codes globally like the US's BRC (1999), and the Sarbanes-Oxley Act (2002) reports, EM continues to receive global attention (Stubben, 2010). Additionally, Kothari et al. (2015) state that the voluminous literature on EM indicates that managers continue to falsify the financial information of firms with the interior motive of skewing the company's stock market price upward.

One of the main issues that arise to deal with EM is the external auditors. It is widely recognized that auditing is a cornerstone in developing and enhancing the global economy and business 
firms. In a context business environment, auditors are required to provide objective assessments concerning whether companies are managed responsibly and effectively to achieve the intended results. Andersen (2000) suggests the role of auditors could be distinguished into five: objectives, reporting lines, profession, and interactions with others. This is important for the companies to achieve accountability, improve operations, and instill confidence among stakeholders. In this perspective, Al-Khaddash et al. (2013) are of opinion that the stakeholders need to gain assurance that the data being reported are properly measured and fairly presented. Accordingly, auditors must raise their capability and independence level, use appropriate tools, and provide advisory services to fulfill each of their roles. There is a growing literature examining the relationship between audit quality and EM, suggesting that the use of higherquality auditors is positively related to less EM (e.g., De Angelo, 1981). De Angelo (1981) holds that the size of the audit firm could be used as a proxy for audit quality because larger firms; presuming that larger audit firms are better equipped and are more independent. In other words, the audit quality increase as the size of the audit firm gets larger. In contrast, a number of studies provided evidence that Big Four auditors (as a proxy for higher quality audit) may not provide higher audit quality than non-Big Four auditors (Saleh, Latif, \&Bakar, 2018a; Saleh, Latif, \&Bakar, 2018b; Saleh, Latif, \&Bakar, 2018c; Stubben, 2010). In other cases, for example, Kothari et al. (2015) suggest that there is no difference in audit quality between Big Six and nonBig Six auditors. The authors suggested that the EM practices are not influenced by auditors' intervention. It actually depends on the institutional setting established and adhered to encourage high-quality audits. Likewise, in the context of Greece cases, Tsipouridou and Spathis (2012) found that there is no significant difference between EM practices of firms audited by Big Four auditors and non-Big Four auditors. AlKhaddash et al. (2013) are of opinion that audit firm size is irrelevant in the selection of an auditor. According to the authors, there might be several factors that affect audit quality; emphasizing audit quality is not just affected by audit firm size.

Several studies have been conducted on corporate governance with the aim of finding solutions to opportunistic EM. However, most of them dwell on board and board characteristics (e.g.Garven\& Taylor, 2015; Rusmin, 2010; Saleh, Latif, Bakar, \&Maigoshi, 2020). In contrast, few other studies worldwide focused on the characteristics of external auditors. The influence of external auditors in lessening EM has not been studied extensively in the developing countries, especially in the Palestinian context.The rest of this paper is organized as follows. Section 2 includes a detailed review of the literature related to audit quality, EM, and hypotheses development. Section 3 provides a discussion on the research methodology. Section 4 concerns the discussion of the results. Lastly, Section 5 provides the conclusion of the study, the limitations of the study as well as a discussion on future research areas will be discussed in this section. 


\section{Literature Review and Hypotheses Development} 2.1 External Auditor's Type Earnings Management

Audit quality and the auditors' independence in mitigating EM can be explained from the perspective of agency theory. Auditing is a means of lessening agency costs (Jensen \&Meckling, 1976). Therefore, when agency cost is higher, the demand for high-quality audits increases (Francis \& Wilson, 1988). It was established that audit quality is a function of the auditor's size (DeAngelo, 1981). Gore, Pope, and Singh (2001) argue that only international audit firms referred to as Big 4 can provide such quality audits. They further argued that the bigger firms are considered more independent with the ability to resist management pressure. Accordingly, extant studies report a negative and significant relationship between audit quality measured by the Big 4 and EM (Garven\& Taylor, 2015; Houqe, Ahmed, \&Zijl, 2017; Rusmin, 2010; Saleh, Shurafa, Shukeri, Nour, \&Maigosh, 2020).

Another argument is that size of auditor including the Big 4 does not guarantee audit quality (Cousin et al., 1998; Shwekeh, Zaid, Saleh, \&Khaleel, 2021). Many at times, the Big 4 are busy and over stretched due to rush for their services, which reduces the quality of services they provide. This increases the possibility for EM. This argument of auditor busyness is consistent with the findings of López and Peters (2012) that audit busy season (end of calendar year) and the workload of the auditor lessen audit quality and increase EM. In view of these contradictory arguments, a non-directional hypothesis is formulated:

\section{H1: There is a negative association between external auditors' type and EM in Palestine.}

\subsection{External Auditor's Independence and Earnings Management}

Agency theory advocates the need for an independent external auditor to verify the accounting numbers prepared and submitted by the management (Jensen \&Meckling, 1976). Auditors have a vital role to play in the process of financial reporting and are capable of mitigating EM. Saleh etal. (2020) postulate that investors get assurance from the auditors on whether the financial statement presented by the firm confirms GAAP (now IFRS) or not. Auditors can only play this monitoring role if they are independent of the management of the firm they audit.

Empirically, a positive association was established between audit tenure and external auditors' independence (Okolie, 2014; Olowookere\&Oladejo, 2014). This study used audit tenure of three years to measure external auditors' independence with the assumption that if an auditor stays more than three years with a client might not be independent. The study expects a positive association between audit tenure and EM. Based on the discussed theory and empirical proofs, a hypothesis is developed thus:

H2: There is a positive association between external auditors' independence and EM in Palestine. 


\section{Research Methodology}

\subsection{Population of the Study}

"Population refers to the entire group of people, events, or things of interest that the researcher wishes to investigate" (Sekaran, 2003, p.281). There are 48 listed companies on the PSE as of 31 December 2019. This study focus on all companies quoted on the PSE as at December 31, 2019.The study used two-point filter to arrive at the working population. Firstly, a company must be quoted on or prior to January 1, 2010. Again, it must remain so (not delisted) between January 1, 2010, and December 31, 2019. The purpose of the filtering is to ensure that the firms' publish complete financial reports within the range under consideration of this study. Ten years (20102019) period are to be covered in this study.The data were sourced from the annual reports and accounts of companies available from the website of the PSE.

\subsection{Operationalization and Measurement of Variables}

Dechow, Sloan and Sweeney (1995) model known as the modified Jones model is used to measure EM, which is the dependent variable in this study.Juhmani (2017) asserts that modified Jones model is the most famous and most frequently used model in the detection of EM. Accordingly, the model has been used in many recent studies (Ioualalen,Khemakhem, \&Fontaine, 2015; Juhmani, 2017). Therefore, to enable the study determines nondiscretionary accruals, this study employs pool OLS regressions (with STATA statistical software) to calculate the coefficients for every industry and for each year, using the model below:

TAC/A $i t-1=\alpha 1(1 / \mathrm{A} i t-1)+\alpha 2(\Delta \mathrm{REV} i t / \mathrm{A} i t-1)+\alpha 3(\mathrm{PPE} i t / \mathrm{A} i t-1)+\mu i t-1$.

Discretionary accruals (DAC) in the event period are:

DAC $i t=$ TAC/A $i t-1-[\alpha 1(1 / \mathrm{A} i t-1)+\alpha 2(\Delta$ REV $i t / A$ it $-1-\Delta$ REC $i t / A$ it-1) $+\alpha 3$ (PPE $i t /$ A $i t-1)]$.

Where TAC $i t=$ total accruals for firm $\mathrm{i}$ in year $\mathrm{t}$ calculated as PBT-CFO

PBT $=$ Profit before tax

$\mathrm{CFO}=$ cash flow from operating activities

A $i t-1=$ total assets for firm $\mathrm{i}$ in the previous year.

$\Delta$ REV $i t / \mathrm{A} i t-1=$ stand for variation in revenues from $i$ in year $t$.

$\Delta \mathrm{REC}=$ is a variation in accruals receivables for firm $i$ in period $t$.

PPE it/ A $i t-1=$ gross property and equipment for firm $i$ in year $t$.

$\mu i t-1=$ error term for firm $i$ year $t$.

The independent variables of this study are the external audit characteristics namely external auditors' type and external auditors' independence.External auditors' type is a measure for audit quality. Big 4 audit firms have been used by previous studies as a proxy for audit quality. However, there is no consensus on the findings. The Big 4 audit firms are Deloitte, PricewaterhouseCoopers (PwC), Ernst \& Young (E \& Y) and Klynveld Peat Marwick Goerdeler (KPMG). Besides, external auditors' independence is required to ensure that financial reporting numbers prepared and submitted by the auditors are reliable. The assumption is that the auditor loses independence with a longer audit period. This study measures external auditors' independence through a dummy variable that considers the value of " 1 " if the external auditor is 
above three years with a client and, "0" otherwise. The study regression equation is modeled as follows:

$$
\begin{aligned}
D A C_{i t}= & \beta_{0}+\beta_{1} E A T Y P E_{i t}+\beta_{2} E A I N D_{i t}++\sum \text { YEAR DUMMY }+\sum \text { INDUSTRY } \\
& \text { DUMMY }+\varepsilon
\end{aligned}
$$

Where;

DAC $=$ Discretionary accruals, TAC/A it- $1-[\alpha 1(1 / \mathrm{A}$ it-1 $)+\alpha 2(\Delta \mathrm{REV}$ it/A it- $1-\Delta \mathrm{REC}$ it/A it- 1$)+\alpha 3$ (PPE it/ A it-1)].

EATYPE = External auditors' type (dummy variable that considers the value of " 1 " if the external auditors is Big 4, " 0 " otherwise).

EAIND = External auditors' Independence (dummy variable that considers the value of " 1 " if the external auditors is above 3 years with the client " 0 " otherwise).

$e_{i t}=$ Error Tem for firm i in period $\mathrm{t}$.

\section{Data Analysis}

\subsection{Descriptive Analysis}

Descriptive analysis is used to describe phenomena of interest (Ayyash\& Abdel Jawad, 2020; Sekaran, 2003). Table 4.4 depicts descriptive statistics of the variables. It shows that themean for the discretionary accruals (absolute value) is 0.18 . The value is higher than that of Khalil and Ozkan (2016) that reported 0.095 for Egyptian firms. The least discretionary accrual is 6.01, which differs from zero. That indicates that the companies under consideration engage in EM. The highest value of discretionary accruals is 22.99 .

Table 1. Descriptive Analysis

\begin{tabular}{lrrrrrr}
\hline & Mean & Std. Dev. & min & max & skewness & kurtosis \\
\hline DAC & 0.18 & 2.09 & 6.01 & 22.99 & 0.41 & 0.01 \\
EATYPE & 0.64 & 0.44 & 0.00 & 1.00 & 0.00 & 0.71 \\
EAIND & 0.55 & 0.22 & 0.00 & 1.00 & 0.59 & 0.01 \\
\hline
\end{tabular}

Note: DAC discretionary accrualsEATYPEreturn on assets, EAIND institutional ownership.

On the external audit characteristics, external auditors' type (EATYPE) being a dichotomous variable has an average of $64 \%$. It indicates that 307 firm's years in the sample data were audited by the Big 4, as against 173 firms' year by the non-Big 4 auditors. It further shows that many (64\%) listed companies in Palestine have a high-quality audit expected to mitigate EM.regarding the external auditors' independence (EAIND), which is also a dichotomous variable. It has an average of $55 \%$, a minimum of zero, and a maximum of one. This indicates that most listed companies in Palestine maintain an external auditor for more than three (3) years consecutively. 


\subsection{Diagnostic Tests}

Hair et al., (2010) suggest that variables should be tested for normality, multicollinearity and heteroscedasticity prior to regression. The correlation matrix of the variables reveals that there is no multicollinearity problem between the variables since the highest correlation between the variables was 55\%. Besides, the result of Breusch-Pagan / Cook-Weisberg test for heteroscedasticityis (prob>chi $2=0.6122$ ), The benchmark is when $H_{0}$ (constant variance) pvalue is above 0.05 , meaning that the variance is homoscedastic. On the other hand, the Wooldridge test for the autocorrelation found that the value is more than $5 \%$, therefore, the null hypothesis was accepted (Sabri, \&Sweis, 2016).Furthermore, to mitigate the extreme values bias, the entire variables were winsorizedat $1 \%$ from top to bottom.

\subsection{Empirical Results and Analysis}

The results, findings, and discussion of the present study are presented in this section. This study applied pooled OLS cross-sectional data analyses to test the association between external audit characteristics and discretionary accruals. This is because the result of Breusch-Pagan/cookWeisberg test $(\operatorname{chi} 2(1)=3.01$, prob $>$ chi2 $=0.1115)$. Skewness and Kurtosis (as in Table 1$)$ are used to check the normality of variables. According to Hair, Black, Babin and Anderson (2010) the benchmark for skewness is $+/-3$, while that of Kurtosis is $+/-10$ as recommended by Kline (1998). The skewness and kurtosis are within the accepted range.Table 2 presents the results of the regressions using OLS techniques.

Table 2. Multiple Regression Results

\begin{tabular}{lccrrr}
\hline DAC & Coef. & St.Err. & t-value & p-value & Sig \\
\hline EATYPE & -.0121 & 0.011 & -2.42 & 0.010 & $* *$ \\
EAIND & 0.017 & 0.004 & 1.39 & 0.080 & $*$ \\
Constant & 0.116 & 0.029 & 1.77 & 0.038 & $* *$ \\
Year dummy & YES & & & & \\
Industry dummy & YES & & & & \\
No. of obs. & $\mathbf{4 8 0}$ & & & & \\
R-squared & $\mathbf{0 . 3 1 0}$ & & & & \\
Prob> F & $\mathbf{0 . 0 0 0}$ & & & & \\
\hline
\end{tabular}

Note: EATYPEreturn on assets, EAIND institutional ownership. *** $p<0.01, * * p<0.05$, * $p<0.1$.

The result of the $R^{2}$ (31\%) means that $31 \%$ of the explanatory variables explained the model.External auditor's type (EATYPE) is expected to have a negative significant relationship with discretionary accruals. The result supports the prediction of this study and agency theory. Agency theory put forward that to lessen agency cost high-quality audit is needed(Jensen \&Meckling, 1976). Some prior researchers opined that a high-quality audit depends on the size of the external auditor (Deangelo, 1981;Garven\& Taylor, 2015).

The second external audit committee characteristic (EAIND) measured by audit tenure is predicted to have a positive and significant relationship with the discretionary accruals. Table 4.12 under model 1 depicts a significant positive relationship between external auditors' independence and discretionary accruals (p-value 0.08), thereby supporting hypothesis 2 . This 
result means that long audit tenure decreases external auditors' independence and increases EM. The result supports agency theory that for auditing to reduce agency cost, the auditor must be independent (Jensen \& Meckling, 1976).

\section{Conclusion}

Two hypotheses were developed. The first hypothesis finds that external auditors' type (proxied by the Big 4 audit firm) is negative and significantly associated with EM. The result is consistent with the agency theory that quality audit lessens agency costs. The second hypothesis finds a positive association between external auditors' independence and EM. This is in agreement with the prediction of the study and agency theory. The agency theory put forward that for external audit to minimize agency cost, the independence of the auditor is necessary.Professional bodies, big4 and non-big4 companies such as will find the study useful. They need to understand their role in ensuring quality and reliable audits in order to reduce EM. The auditors also need to be independent of the management of the company they are auditing. This study establishes that external auditors' type and to a certain extent, external auditors' independence affect the level of discretionary accruals. This study recommends future studies to consider other types of explanatory variables that could reduce the EM practices, such as capital structure, ownership structures, and audit committee characteristics.Second, due to the mixed results in the prior literature which could be attributable to failure addressing the endogeneity issue, this study recommends future research using a one-step system generalized method of moments (GMM) to deal with the endogeneity problem. This may provide better and more accurate results.

\section{Acknowledgements}

The authors thank Palestine Technical University- Khadoorei for its supports.

\section{Declaration of competing interest}

The authors declare that they have no conflict of interest

\section{References:}

1. Al-Khaddash, H., Al-Nawas, R., Ramadan, A. (2013), "Factors affecting the quality of Auditing: The Case of Jordanian Commercial Banks", International Journal of Business and Social Science, 4 (11), 206-222

2. Andersen, A. (2000), "The Role of the Auditor", presented in Seminar for Senior Bank Supervisors from Emerging Economies, available at http://www.worldbank.org

3. Ayyash, I, Abdel Jawad, Y.(2020) The Competitiveness in the Banking Industry in Palestine. International Journal of Economics and Financial Issues. 2020, 10(1), 201 208.

4. Cousins, J., Mitchell, A., Sikka, P., \&Willmott, H. (1998). Auditors: Holding the public to ransom. Association for Accountancy Business Affairs. Retrieved from http://visar.csustan.edu/aaba/ransom.PDF 
5. DeAngelo, L. E. (1981). Auditor size and audit quality. Journal of accounting and economics, 3(3), 183-199.

6. Dechow, P. M., Sloan, R. G., \& Sweeney, A. P. (1995). Detecting Earnings Management. The Accounting Review, 70(2), 193-225.

7. Francis, J. R., \& Wilson, E. R. (1988). Auditor changes: A joint test of theory relating to agency costs and auditor differentiation. Accounting Review, 63(4), 663.

8. Garven, S., \& Taylor, G. (2015). Big 4 auditor office size, analysts' annual earnings forecasts and client earnings management behavior. Academy of Accounting and Financial Studies Journal, 19(3), 103.

9. Gore, P., Pope, P., \& Singh, A. (2001). Non-audit services, auditor independence and Earnings Management. Retrieved from http://eprints.lancs.ac.uk/30475/

10. Hair, J. F., Black, W. C., Babin, B. J., \& Anderson, R. E. (2010). Canonical correlation: A supplement to multivariate data analysis. Multivariate data analysis: a global perspective. 7th edn. Pearson Prentice Hall Publishing, Upper Saddle River.

11. Houqe, M. N., Ahmed, K., \&Zijl, T. (2017). Audit Quality, Earnings Management, and Cost of Equity Capital: Evidence from India. International Journal of Auditing.

12. Ioualalen, L., Khemakhem, H., \& Fontaine, R. (2015). The impact of audit committee characteristics on earnings management: A Canadian case study. Case Studies in Business and Management, 2(1), 78.

13. Jensen, M.C. \&Meckling, W. H., (1976). Theory of the firm: Managerial behavior, agency costs and ownership structure. Journal of Financial Economics, 3(4), 305-360.

14. Juhmani, O. I. (2017). Audit Committee Characteristics and Earnings Management: The Case of Bahrain. International Journal of Accounting and Financial Reporting, 7(1), 1232.

15. Khalil, M., \&Ozkan, A. (2016). Board independence, audit quality and Earnings Management: evidence from Egypt. Journal of Emerging Market Finance, 0972652715623701.

16. Kline, R. B. (1998). Software review: Software programs for structural equation modeling: Amos, EQS, and LISREL. Journal of psychoeducational assessment, 16(4), 343-364.

17. Kothari, S. P., Mizik, N., \&Roychowdhury, S. (2015). Managing for the moment: The role of Earnings Management via real activities versus accruals in SEO valuation. The Accounting Review, 91(2), 559-586.

18. López, D. M., \& Peters, G. F. (2012). The effect of workload compression on audit quality. Auditing: A Journal of Practice \& Theory, 31(4), 139-165.

19. Okolie, A. O. (2014). Auditor tenure, auditor independence and accrual-based earnings management of quoted companies in Nigeria. European Journal of Accounting Auditing and Finance Research, 2(2), 63-90. 
20. Olowookere, J. K., \&Oladejo, M. O. (2014). Influence of remuneration and tenure on auditors' independence in Nigeria. IOSR Journal of Business and Management, 16(5), 612.

21. Rusmin, R. (2010). Auditor quality and earnings management: Singaporean evidence. Managerial Auditing Journal, 25(7), 618-638.

22. Sabri, T. B. H., \&Sweis, K. M. H. (2016). Effect of corporate social responsibility on profitability of banks working in Palestine (case study 2013-2014). International Journal of Business Administration, 7(6), 107.

23. Saleh, M. W., Latif, R. A., \&Bakar, F. A. (2018b). The Impact of Ownership Structure on the Performance ofPalestinian Listed Companies. International Journal of Business Marketing and Management (IJBMM). 3(9), 16-21.

24. Saleh, M. W., Shurafa, R., Shukeri, S. N., Nour, A. I., \&Maigosh, Z. S. (2020). The effect of board multiple directorships and CEO characteristics on firm performance: evidence from Palestine. Journal of Accounting in Emerging Economies. 10(4), 637-654. DOI 10.1108/JAEE-12-2019-0231

25. Saleh, M.W., Latif, R.A. and Bakar, F.A. (2018a). A conceptual framework for the role of corporate social responsibility in Palestinian firm performance. Journal of Accounting and Finance in Emerging Economies. 4(2), 141 150.DOI: https://doi.org/10.26710/jafee.v4i2.527

26. Saleh, M.W., Latif, R.A., Bakar, F.A. and Maigoshi, Z.S. (2020). The impact of multiple directorships, board characteristics, and ownership on the performance of Palestinian listed companies. International Journal of Accounting, Auditing and Performance Evaluation. 16(1), 63-80. DOI 10.1504/IJAAPE.2020.106774.

27. Saleh, M.W.A., Abdul Latif, R. and Abu Bakar, F. (2018). The role of CEO experience and CEO multiple directorships in Palestinian firm performance: the moderating effect of political connection. Journal of Advanced Research in Business and Management Studies. 10(1), 1-9, ISSN. 2462-1935

28. Sekaran, U. (2003). Research methods for business- A Skill-Building Approach. Retrieved from http://www.wiley.com/college

29. Shwekeh, A., Zaid, A. A., Saleh, M. W. A., \&Khaleel, M. M. M. (2021). The Impact of Economic Indicators on Food Supply Chain of Palestine. Journal of University of Shanghai for Science and Technology, 23(1), 264275.http://doi.org/10.51201/Jusst12555

30. Stubben, S. R. (2010). Discretionary revenues as a measure of earnings management. Accounting Review, 85(2), 695-717.

31. Tsipouridou, M. and Spathis, C. (2012), "Earnings management and the role of auditors in an unusual IFRS context: The case of Greece”, Journal of International Accounting, Auditing and Taxation, 21 (1), 62-78 